\title{
INTERACTIVE DIGITAL MEDIA AND IMPACT OF CUSTOMER ATTITUDE AND TECHNOLOGY ON BRAND AWARENESS: EVIDENCE FROM THE SOUTH ASIAN COUNTRIES
}

\author{
Rizwan Raheem AHMED ${ }^{1}$, Jolita VVEINHARDT ${ }^{2}$, Dalia STREIMIKIENE ${ }^{3}$ \\ ${ }^{1}$ Faculty of Management Sciences, Indus University, ST-2D, Block-17, \\ Gulshan, Karachi-75300, Pakistan \\ ${ }^{2,3}$ Institute of Sport Science and Innovations, Lithuanian Sports University, \\ Sporto str. 6, Kaunas LT-44221, Lithuania \\ E-mails: ${ }^{1}$ rizwanraheemahmed@gmail.com (corresponding author); \\ 2jolita.vveinhardt@gmail.com; ${ }^{3}$ dalia.streimikiene@lei.lt
}

Received 24 Jun 2017; accepted 31 Oct 2017

\begin{abstract}
The purpose of this study is to investigate the role of interactive digital media channels such as social media, email marketing, and mobile marketing in creating the brand awareness. We have assimilated three behavioral factors including perceived value, trust, and word of mouth as mediating factors, and the Internet and smartphone as moderating variable. Total 2565 responses have been taken to investigate the role of digital media channels, and impact of mediating and moderating variables on the brand awareness. This research has used SEM-based multivariate approach including exploratory factor analysis, confirmatory factor analysis, and conditional process technique for examining the direct and indirect influence of variables. The results of the study exhibited that the interactive digital media channels have a positive and significant direct impact on brand awareness. Results further revealed that the perceived value, trust, and word of mouth as mediating factors, and the Internet and smartphone as moderating variables have a significant and influential impact in a relationship of interactive digital media tools and the brand awareness.
\end{abstract}

Keywords: interactive digital media, SEM-based approach, mobile marketing, email marketing, social media marketing, brand awareness, technology.

JEL Classification: C12, L60, L80, M3.

\section{Introduction}

The digitized world has revolutionized every facet of life whether it is professional or personal. One of the most significant and visible evidence of this transition is the advancement in communication channels, as an emergence of new communication channels with Internet compatibility has been termed digital communication tools (Romaniuk et al. 2017; Çizmeci, Ercan 2015). The digitized access to the world crops up the concept of emails, SMS, MMS, Facebook, Twitter, and LinkedIn etc. as social media similar to others. Individuals and corporate interaction are become very interac- 
tive because of blogs, URLs and search engines (Blair 2017). People having access to the digital means of communication are no more content with texting only; rather they intend to transmit their feelings, opinions, and criticism on the contents of information wherever they feel interference is needed. The digital avenue provides an opportunity to its users not only to access the information but also become the source of information generation (Weber 2009). Digital means of communication like email forums are recognized as the cost-effective and time saving mechanism. This further enables the companies and entrepreneurs to connect the consumers and companies globally in a swift manner (Confos, Devis 2016). The marketing specialists have termed the digital means of communication as 'digital marketing tools'. Fortune entrepreneurs have efficiently utilized the new interactive digital marketing channels to enhance the brand awareness of their strategic products (Çizmeci, Ercan 2015).

This study is an attempt to examine this new kind of interactive digital media, and its use in the marketing communication. There are several effective digital media tools in which mobile marketing, social media marketing, and email marketing have a significant role in current IMC plans for the organizations. Hence, the purpose of this study is to investigate the role of online digital media and its impact on brand awareness. The topic of digital media channels has gained the tremendous attention of researchers in recent times, and meaningful literature is available on the role of digital media in advertising (Stephen 2016; Saini 2017). Some studies have been carried out on the role of digital media channels' effectiveness that demonstrate the importance of digital media in creating the brand awareness, and underlying factors of customers' motivation for using the online media channels (Romaniuk et al. 2017; Dimitriu, Guesalaga 2017). But the available current literature does not elaborate the real-time impact of technology and its dimensions on consumers' behavior and brand awareness by using digital media communication channels. Moreover, the novelty of undertaken research is many folds, besides the role of interactive digital communication channels; this study also analyzed the behavior of customers. For this reason, three important behavioral aspects including word of mouth, perceived value and trust have been incorporated as mediating variables. Conclusively, the technological factors also played a vital role in online digital media channels. Thus, in this research two important technological factors including the Internet and smartphones have been taken as moderating variable, and evaluate the impact of technology on digital media channels and the brand awareness.

\section{Conceptual frameworks}

In this part, we have developed the conceptual framework of undertaken research by using the previous literature.

\subsection{The initiating phases of marketing communication: the brand awareness}

Developing the "Brand Awareness" paves the way for a brand to win its due recognition among other brands in the marketplace. Distinguishing of the "Brand" means the customer prioritizes the brand over other rivalry brands in the market. Thus, the concept of brand awareness signifies to the amount of influence of a brand in the brains of cus- 
tomers (Aaker 1996). The brand awareness may also be defined as a component, which establishes the elementary step for the happening of interaction among the organizations and customers that are required to occur prior to all rest of the steps in that process (Rossiter, Percy 2017). This confirms that, brand awareness is the main component, which influences the consumer behavior, and that in turn makes the consumer set the brand preferences. The unavailability of brand awareness lacks the buying decision (Baldauf et al. 2003). Brand awareness does not merely mean to have acquaintance with a brand or has interaction with it before; rather it describes the consumers' affiliation with its name and trademark (Filipovic 2015).

\subsection{Digital marketing communication tools}

Digital marketing has given the new directions to the traditional marketing pattern via providing the commonplace for the customers to share the ideas. Digital marketing provides the facility to the marketers and consumers based on the real-time, location for faster response. Digital marketers use interactive and digital features for providing information and sorting the customers based on their requirements, so in this way, it is an excellent and the most effective media channels to create the brand awareness (Chitra, Sasikala 2016).

\subsection{Technology and digital marketing media}

It is very difficult for the marketers to market the products in this digital era without considering the importance of advanced digital technology. Digital marketing is also very beneficial for the companies as the digital marketing is cost-efficient advertisement method. The Internet and smartphones are the most perceptible channels for the advertisers, which made the evolution in digital marketing (Ahuja 2015).

\subsection{Internet: a new era of marketing communication}

The Internet has completely transformed the methods of communication across the globe. This advancement in technology enabled the consumers to sort out the brands that were not possible earlier. Now, in globalized world, the consumers have more and easy access to the digital media. This accessibility enables them to create brand awareness and then decide about their purchases among the available brands (Chitra, Sasikala 2016). The latest report of 2017 showed that the Internet users crossed more than 3.7 billion as on March 31, 2017 (Blair 2017). This also enables companies to know about the product and the transmission of those modifications proposed by the consumers that definitely enhances the brand awareness (Baldauf et al. 2003). Ease in the purchasing has compelled the consumers to use the Internet as it provides 24/7 non-stop facilities for purchasing without any hectic. A drastic change in consumer-marketer relationship increases as the more opportunities available to them. There is a tendency of potential challenge prevail for the digital marketers while they do not prepare from every angle for creating brand awareness (Filipovic 2015). Hence, we made following hypotheses by using the Internet as moderating variable:

$\mathbf{H}_{\mathbf{1 A}}$ : The email marketing channel and the brand awareness will be moderated by the Internet development. 
$\mathbf{H}_{1 \mathbf{B}}$ : The mobile marketing channel and the brand awareness will be moderated by the Internet development.

$\mathbf{H}_{1 \mathbf{C}}$ : The social media marketing channel and the brand awareness will be moderated by the Internet development.

\subsection{Smartphones: smart era of marketing communication}

Mobile phones that contain default applications and having the more advanced features of the Internet than the traditional one is called a smartphone. This technology has made the revolution in the way of interaction with the consumers, free voice facility, utility payments lending facility to the personal businesses (Blair 2017). Cell phone marketing is denoted as the marketing via smartphone gadget that incorporates SMS's, web pages, codes, and multiple smartphone application advertisements. Marketers use location wise advertising technique in order to concentrate their segmented consumers. However, the literature of mobile marketing is very limited and does not cover its all the sides and channels (Harrison, Jackson 2013; Munsell et al. 2015). It is evident that there are more than a million apps are available for the android and apple smartphones, so it would be wise decisions for companies to opt this strategy for their advertisement and brand awareness (Romaniuk et al. 2017). Thus, we made following hypotheses by using the smartphone as moderating variable:

$\mathbf{H}_{\mathbf{2 A}}$ : The email marketing channel and the brand awareness will be moderated by the smartphones.

$\mathbf{H}_{\mathbf{2 B}}$ : The mobile marketing channel and the brand awareness will be moderated by the smartphones.

$\mathbf{H}_{\mathbf{2}}$ : The social media marketing channel and the brand awareness will be moderated by the smartphones.

\subsection{Email marketing and brand awareness}

It simply refers using email as a source of transmitting advertising messages, which ultimately increases the brand awareness across the globe. Earlier in the year 2005, users of global email increased to 683 million, the number is swelled to 1.2 billion and end of 2015 it reached around 4.4 billion. Thus, email marketing has now become one of the most prominent online media channels for brand awareness and advertising across the globe, and marketers are using this medium because of high response rate (Talarico 2016). The use of email marketing channel is widely used for B2B marketing, the reason behind the wider use of this medium is the number of users, high response rate, and the most cost-effectiveness (Zhang et al. 2017). According to Clark and Melancon (2013), the American companies have increased their budgets by $60 \%$ for this medium, another study mentioned that global companies have increased their budget by $58 \%$ for alone email marketing (Gopal et al. 2006). Thus, we have constructed the following hypothesis:

$\mathbf{H}_{3}$ : The Email marketing channel will have a positive impact on the brand awareness. 


\subsection{Mobile phone marketing and brand awareness}

A tremendous increase in the cell phones worldwide opened up a new advertising medium for companies to reach out their customers effectively (Çizmeci, Ercan 2015). The most widely used tool of mobile phone marketing is the SMS (short message service) text advertising, and marketers learn that the SMS texting is an efficient and the costeffective tool as compared to the conventional advertising channels (Muk, Chung 2015). The previous literature demonstrated that the SMS advertising is being used widely because of its unique characteristics, easy to target specific pool of customers, and realtime interactive features (Al-Meshal, Almotairi 2013). The SMS advertising could be used for a diverse group of customers with lower cost than the traditional media, and the most important reason for using this medium is because of the high reading rate of 99\% (Choi, Lee 2015). Thus, the mobile marketing makes organizations to build their brand through brand awareness and increase brand loyalty (Munsell et al. 2015). Thus, we have constructed the following hypothesis:

$\mathbf{H}_{4}$ : The mobile phone marketing channel will have a positive impact on the brand awareness.

\subsection{Social media marketing and brand awareness}

Social media has a unique characteristic to engage customers online in a real-time, which makes strong customer relationship that enables marketers to create brand awareness (Çizmeci, Ercan 2015). The social media provides opportunities to the communities to intermingle and discuss their opinions and exposures vis-à-vis a particular product. The popular social media includes Facebook, YouTube, Twitter, MySpace, Google Plus, Snap Chat, Flickr, and LinkedIn etc. The social media provides opportunities for networking between customer and organizations that provide a number of benefits including brand reach, brand awareness, customer transactions, reputation, and referrals (Kaplan, Haenlein 2010). In social media the companies are using this channel as a tactical and meticulous manner to create the corporate image, brand awareness, company's influence, brand equity, and brand loyalty within the communities (Blair 2017). The unique characteristics of social media make it the most popular, very effective and revolutionized marketing channel for advertising and promotion (Hanna et al. 2011). Thus, we have constructed the following hypothesis:

$\mathbf{H}_{5}$ : The social media-marketing channel will have a positive impact on the brand awareness.

\subsection{Customers' attitude towards digital media marketing and brand awareness}

Consumers' attitude towards digital media marketing communication has been examined in several previous research studies; the researchers used perceived value, trust, and word of mouth as mediating variables.

\subsubsection{Perceived value}

According to Zeithaml (1988), the perceived value is defined, as "it is the consumers' overall evaluation of the goods and services between the offered and received features and benefits". Several researchers have carried out studies on the relationship of perceived value and brand awareness. As Çizmeci and Ercan (2015), and Baldauf et al. 
(2003) have concluded a positive and strong association between brand awareness and perceived value. If the customers receive the anticipated and favorable benefits from the products then they even ready to pay the premium price. According to several research studies, the perceived value is played a vital role while consumers making purchase decision, and consumers always prefer to buy that brand, which has higher perceived value (Ailawadi et al. 2003). Thus, we made following hypotheses by using the perceived value as mediating variable:

$\mathbf{H}_{6 \mathrm{~A}}$ : The email-marketing tool and brand awareness will be mediated by the perceived value.

$\mathbf{H}_{\mathbf{6 B}}$ : The mobile phones marketing tool and brand awareness will be mediated by the perceived value.

$\mathbf{H}_{\mathbf{6}}$ : The social media-marketing tool and brand awareness will be mediated by the perceived value.

\subsubsection{Trust}

Several previous studies have discussed the elements of trust, brand association, brand image, and brand awareness (Ribbink et al. 2004). The existing literature also confirmed the effect of digital media on the brand awareness and trust (Yoon 2002). The literature demonstrated that the trust is considered to be the major and fundamental factor for the explanation of brand awareness and brand loyalty (Pizzutti, Fernandes 2010). The literature established that the trust has a significant and positive effect on brand awareness (Yasin, Shamim 2013). Çizmeci and Ercan (2015) have proven the positive impact of interactive digital media channels, trust, brand loyalty, and brand awareness. They further demonstrated that the trust created the brand loyalty and brand awareness, and it is continuous process amid the brand and the customer. Mourad et al. (2011) showed that the brand awareness is the antecedent of trust, however, the trust directly affected the brand loyalty. Thus, we made following hypotheses by using the trust as mediating variable:

$\mathbf{H}_{7 \mathrm{~A}}$ : The email marketing channel and the brand awareness will be mediated by the trust.

$\mathbf{H}_{7 \mathbf{B}}$ : The mobile marketing channel and the brand awareness will be mediated by the trust.

$\mathbf{H}_{7 \mathbf{C}}$ : The social media marketing channel and the brand awareness will be mediated by the trust.

\subsubsection{Word of mouth}

The satisfied customers are the assets for any organization because the satisfied customer spread positive word of mouth, which enhances the brand awareness (Groeger, Buttle 2016). According to Kotler et al. (2014), the positive word of mouth always remained a key factor in marketing communication, which creates the positive impact on brand awareness, and organizations improve and sustain their competitive advantage. According to Yasin and Shamim (2013), the word of mouth is a significant mediating factor, which enhances the brand awareness and brand equity through online media channels. According to Virvilaite et al. (2015), the positive information passed by the 
customer about the brand has significant and meaningful influence on the brand awareness. Thus, we have postulated following hypotheses regarding the mediating effect of word of mouth:

$\mathbf{H}_{\mathbf{8 A}}$ : The email marketing channel and the brand awareness will be mediated by the word of mouth.

$\mathbf{H}_{\mathbf{8 B}}$ : The mobile marketing channel and the brand awareness will be mediated by the word of mouth.

$\mathbf{H}_{\mathbf{8 C}}$ : The social media marketing channel and the brand awareness will be mediated by the word of mouth.

\section{Data and research methodology}

\subsection{Targeted population and sample size}

The sample collection method was multifaceted; we used different online channels including Google doc, LinkedIn, Facebook, Researchgate and personal emails. According to Kerlinger and Lee (2000), the required sample size could be calculated by using (1):

$$
n=\left[\frac{\left(Z_{\alpha / 2}\right)^{2} \cdot \sigma^{2}}{e^{2}}\right] \text {, }
$$

where: $n$ - sample size; $\sigma$ - standard deviation; $e$ - sampling tolerance; $Z_{\alpha / 2}-$ value from the normal distribution.

Since we have used 5 points Likert scale questionnaire, thus for 5 points Likert scale, the (1) could be transformed into (2) as:

$$
n=\left[\frac{\left(Z_{\alpha / 2}\right)^{2} \cdot \sigma^{2}}{(5 e)^{2}}\right] \text {, }
$$

where: $\sigma=1.3 ; e=0.02 ; Z=1.96$.

Thus, the minimum required sample is 649.23 , but for more representative results we have calculated the sample sizes from each of country's Internet users as exhibited in Table 1.

Table 1. Targeted populations and sample size

\begin{tabular}{lcc}
\hline \multicolumn{1}{c}{ Name of Country } & Internet Users & Sample size taken \\
\hline India & $462,124,989$ & 1122 \\
\hline Pakistan & $34,342,400$ & 932 \\
\hline Bangladesh & $21,439,070$ & 389 \\
\hline Sri Lanka & $6,087,164$ & 122 \\
\hline Total South Asia & $523,993,623$ & Total sample 2565
\end{tabular}

Source: Country-wise Internet users, Internet Live Stats, July 2016 (Internet live stats (2016); and authors' calculation. 


\subsection{Research methodology}

This research has used SEM-based multivariate approach to test the hypotheses; structural equation modeling (SEM) was employed to check the causal association amongst the variables. In SEM-based approach, we have employed exploratory factor analysis to test the measurement model, and confirmatory factor analysis for checking the structured statistical model. In confirmatory factor analysis we used principal component analysis to validate the considered factors and constructs, however, total variance explained approach has been used to explain the variance panel among the potential variables. The KMO and Bartlett's analysis has expanded to test the tolerability of the sample. We have also checked the reliabilities and validities of constructs and variables through factor loadings, Cronbach's alpha, composite reliability, and average variance extracted methods. We have checked the suitability of variables of measurement model and structured model through the goodness of fit indices. We have employed conditional process approach for testing the direct and indirect (mediating and moderating) relationship amongst the variables. Finally, we have confirmed the moderating effects of variables through 3D visualization by using conditional process technique (Bolin 2014).

\subsection{Sample description}

In total sample of 2565 , there were $1467(57.19 \%)$ males, and 1098(42.81\%) females, and $1134(44.21 \%)$ respondents were single, $1256(48.97 \%)$ were married, and $175(6.82 \%)$ were divorced. In terms of age, $1452(56.61 \%)$ had $18-30$ years, $659(25.69 \%)$ had $30-40$ years, $345(13.45 \%)$ had $40-50$ years, $109(4.25 \%)$ had $50-60$ years age bracket. In terms of experience, $1089(42.46 \%)$ respondents had $1-5$ years, $767(29.90 \%)$ had 5-10 years, $398(15.52 \%)$ had $10-15$ years, $210(8.19 \%)$ had $15-20$ years, and $101(3.94 \%)$ respondents had greater than 20 years experience. In terms of education, 549(21.40\%) respondents had up to high school diploma, 988(38.52\%) had a formal graduate qualification, $588(22.92 \%)$ had post graduation, and rest $440(17.15 \%)$ respondents had a professional qualification. In terms of income, 709(27.64\%) respondents were in the bracket of 100 $300 \$, 765(29.82 \%)$ were in $300-500 \$$, 538(20.97\%) were in 500-700\$, 345(13.45\%) were in $700-900 \$$, and rest of $208(8.11 \%)$ were in the income bracket of more than $900 \$$ per month.

\section{Estimations and results}

\subsection{Reliabilities, validities and AVE}

According to Leech et al. (2011), the values of reliabilities are considered Excellent $(\alpha \geq 0.90)$, good $(\alpha \geq 0.80)$, and acceptable $(\alpha \geq 0.70)$. The results of Table 2 showed the individual and composite reliabilities are greater or equal to 0.70 , and it is confirmed that the constructs and variables have internal consistency. Moreover, the value of factor loading for each item is less than 0.85 that satisfied the condition of discriminant validity. The correlation between each item and variable is greater than 0.5 , thus, the requirement of convergent validity is also fulfilled (Rutherford et al. 1988). The results of Table 2 also exhibited the square root of average variance extracted (AVE) of considered variables, and showed more than 0.5 that also verified the convergent validity (Fornell, Larcker 1981). 
Table 2. Factor loading and reliabilities

\begin{tabular}{|c|c|c|c|c|c|}
\hline \multicolumn{2}{|c|}{ Variables and constructs } & $\begin{array}{l}\text { Factor } \\
\text { Loading }\end{array}$ & $\begin{array}{l}\text { Cronbach's } \\
\text { Alpha }\end{array}$ & $\begin{array}{l}\text { Composite } \\
\text { Reliability }\end{array}$ & AVE \\
\hline \multirow{3}{*}{ Brand Awareness } & BA1 & 0.81 & \multirow{3}{*}{0.73} & \multirow{3}{*}{0.75} & \multirow{3}{*}{0.71} \\
\hline & BA2 & 0.77 & & & \\
\hline & BA3 & 0.67 & & & \\
\hline \multirow{3}{*}{ Email Marketing } & EM1 & 0.73 & \multirow{3}{*}{0.71} & \multirow{3}{*}{0.73} & \multirow{3}{*}{0.68} \\
\hline & EM2 & 0.68 & & & \\
\hline & EM3 & 0.76 & & & \\
\hline \multirow{3}{*}{ Mobile Marketing } & MM1 & 0.69 & \multirow{3}{*}{0.72} & \multirow{3}{*}{0.74} & \multirow{3}{*}{0.69} \\
\hline & MM2 & 0.73 & & & \\
\hline & MM3 & 0.76 & & & \\
\hline \multirow{4}{*}{ Social Media Marketing } & SMM1 & 0.69 & \multirow{4}{*}{0.74} & \multirow{4}{*}{0.76} & \multirow{4}{*}{0.73} \\
\hline & SMM2 & 0.79 & & & \\
\hline & SMM3 & 0.78 & & & \\
\hline & SMM4 & 0.69 & & & \\
\hline \multirow{3}{*}{ Perceived Value } & PV1 & 0.65 & \multirow{3}{*}{0.73} & \multirow{3}{*}{0.75} & \multirow{3}{*}{0.71} \\
\hline & PV2 & 0.78 & & & \\
\hline & PV3 & 0.77 & & & \\
\hline \multirow{3}{*}{ Trust } & TRU1 & 0.73 & \multirow{3}{*}{0.70} & \multirow{3}{*}{0.71} & \multirow{3}{*}{0.67} \\
\hline & TRU2 & 0.67 & & & \\
\hline & TRU3 & 0.71 & & & \\
\hline \multirow{3}{*}{ Word of Mouth } & WOM1 & 0.82 & \multirow{3}{*}{0.76} & \multirow{3}{*}{0.78} & \multirow{3}{*}{0.72} \\
\hline & WOM2 & 0.74 & & & \\
\hline & WOM3 & 0.67 & & & \\
\hline \multirow{3}{*}{ Internet } & INT1 & 0.68 & \multirow{3}{*}{0.72} & \multirow{3}{*}{0.74} & \\
\hline & INT2 & 0.69 & & & 0.68 \\
\hline & INT3 & 0.79 & & & \\
\hline & SMP1 & 0.73 & & & \\
\hline Smartphone & SMP2 & 0.76 & 0.71 & 0.73 & 0.69 \\
\hline & SMP3 & 0.67 & & & \\
\hline
\end{tabular}

\subsection{Kaiser-Meyer-Olkin and Bartlett's analyses}

We have conducted the Kaiser-Meyer-Olkin (KMO) analysis to measure the sampling adequacy. The results of Table 3 showed that the value of KMO for all the constructs is 0.864 , which shows the accuracy of our sampling against the cut-off of 0.50 . The analysis of Bartlett's test of sphericity demonstrated that there is a substantial variance in the properties of correlation and identity matrices because of the $p<0.05$ (Leech et al. 2011). 
Table 3. Results of Kaiser-Meyer-Olkin and Bartlett's tests

\begin{tabular}{ccc}
\hline \multicolumn{2}{c}{ Kaiser-Meyer-Olkin Measure of sampling adequacy } & 0.864 \\
\hline Bartlett's test of sphericity & Approx. Chi-Square & 35330.739 \\
\cline { 2 - 3 } & Df & 36 \\
\cline { 2 - 3 } & Sig. & 0.0000 \\
\hline
\end{tabular}

\subsection{Total variance explained}

The analysis of total variance explained has employed to explain the variance panel among the potential variables. According to the cut-off the values of all the factors Eigenvalues should be greater than 1.0. The results of Table 4 confirmed the usefulness of factors because the value of Eigenvalue is greater than 1.0. The results of Table 4 further exhibited that all the nine factors explained the minimum cumulative variance of $77.13 \%$, which is considered very good.

Table 4. Results of total variance explained

\begin{tabular}{ccccccc}
\hline \multirow{2}{*}{ Component } & \multicolumn{3}{c}{ Initial Eigenvalues } & \multicolumn{2}{c}{ Extracted sums of Squared Loadings } \\
\cline { 2 - 6 } & Total & $\begin{array}{c}\text { \% of } \\
\text { Variance }\end{array}$ & $\begin{array}{c}\text { Cumulative } \\
\%\end{array}$ & Total & $\begin{array}{c}\text { \% of } \\
\text { Variance }\end{array}$ & $\begin{array}{c}\text { Cumulative } \\
\%\end{array}$ \\
\hline 1 & 6.942 & 77.128 & 77.128 & 6.942 & 77.128 & 77.128 \\
\hline 2 & 0.992 & 11.017 & 88.145 & & & \\
\hline 3 & 0.420 & 4.666 & 92.812 & & \\
\hline 4 & 0.231 & 2.569 & 95.381 & & \\
\hline 5 & 0.153 & 1.696 & 97.077 & & \\
\hline 6 & 0.112 & 1.248 & 98.325 & & \\
\hline 7 & 0.081 & 0.895 & 99.220 & & \\
\hline 8 & 0.047 & 0.517 & 99.738 & & \\
\hline 9 & 0.024 & 0.262 & 100.000 & & \\
\hline
\end{tabular}

Extraction Method: Principal Component Analysis.

\subsection{Principal component analysis}

Principal component analysis and Varimax rotation methods have been employed in undertaken research. We have characterized our data into 37 questionnaire constructs; the description of each construct is demonstrated in Table 5 . As exhibited by Table 5 the correlation between each set of item and variable is greater than 0.50 , which further validated that our constructs are practically significant and we can proceed for further analysis (Kaiser 1974). 
Table 5. Results of Principal components analysis

\begin{tabular}{|c|c|c|c|c|c|c|c|c|c|c|}
\hline \multicolumn{2}{|c|}{ Variables and constructs } & BA & EM & MM & SMM & PV & TRU & WOM & INT & SMP \\
\hline \multirow{3}{*}{$\begin{array}{l}\text { Brand } \\
\text { Awareness }\end{array}$} & BA1 & 0.81 & & & & & & & & \\
\hline & BA2 & 0.79 & & & & & & & & \\
\hline & BA3 & 0.67 & & & & & & & & \\
\hline \multirow{3}{*}{$\begin{array}{l}\text { Email } \\
\text { Marketing }\end{array}$} & EM1 & & 0.73 & & & & & & & \\
\hline & EM2 & & 0.81 & & & & & & & \\
\hline & EM3 & & 0.79 & & & & & & & \\
\hline \multirow{3}{*}{$\begin{array}{l}\text { Mobile } \\
\text { Marketing }\end{array}$} & MM1 & & & 0.81 & & & & & & \\
\hline & MM2 & & & 0.79 & & & & & & \\
\hline & MM3 & & & 0.67 & & & & & & \\
\hline \multirow{4}{*}{$\begin{array}{l}\text { Social Media } \\
\text { Marketing }\end{array}$} & SMM1 & & & & 0.73 & & & & & \\
\hline & SMM2 & & & & 0.81 & & & & & \\
\hline & SMM3 & & & & 0.79 & & & & & \\
\hline & SMM4 & & & & 0.67 & & & & & \\
\hline \multirow{3}{*}{$\begin{array}{l}\text { Perceived } \\
\text { Value }\end{array}$} & PV1 & & & & & 0.71 & & & & \\
\hline & PV2 & & & & & 0.80 & & & & \\
\hline & PV3 & & & & & 0.77 & & & & \\
\hline \multirow{3}{*}{ Trust } & TRU1 & & & & & & 0.80 & & & \\
\hline & TRU2 & & & & & & 0.77 & & & \\
\hline & TRU3 & & & & & & 0.54 & & & \\
\hline \multirow{3}{*}{$\begin{array}{l}\text { Word of } \\
\text { Mouth }\end{array}$} & WOM11 & & & & & & & 0.71 & & \\
\hline & WOM2 & & & & & & & 0.80 & & \\
\hline & WOM3 & & & & & & & 0.77 & & \\
\hline \multirow{3}{*}{ Internet } & INT1 & & & & & & & & 0.81 & \\
\hline & INT2 & & & & & & & & 0.79 & \\
\hline & INT3 & & & & & & & & 0.70 & \\
\hline \multirow{3}{*}{ Smartphone } & SMP1 & & & & & & & & & 0.59 \\
\hline & SMP2 & & & & & & & & & 0.71 \\
\hline & SMP3 & & & & & & & & & 0.80 \\
\hline
\end{tabular}

\subsection{Confirmatory factor analysis}

Results of Table 6 exhibited the analysis of confirmatory factor analysis for all the constructs and factors, which were verified and measured on the basis of documented theories of structural equation modeling (Rutherford et al. 1988). Table 6 showed the summarized results of fit-measures indices for the structured and measured models for all 37 constructs of nine variables. A structural model of digital media marketing tools was carried out to measure the parameters. Results of Table 6 demonstrated the fit-measures indices, and it is determined that our model of study is statistically good 
fit because the values of GFI, NFI, TLI, CFI, RMSEA, RNI and PCFI followed the threshold criterion. Hence, it is demonstrated by the results of Table 6 that 37 constructs of the CFA model are fitted to the sample data.

Table 6. Fit measures indices

\begin{tabular}{lccccccc}
\hline Fit Measures indices & GFI & NFI & TLI & CFI & RMSEA & RNI & PCFI \\
\hline Measurement Model & 0.96 & 0.93 & 0.97 & 0.96 & 0.032 & 0.98 & 0.78 \\
\hline Structural Model & 0.98 & 0.95 & 0.99 & 0.98 & 0.005 & 0.99 & 0.80 \\
\hline Threshold Values & $>0.95$ & $>0.90$ & $>0.95$ & $\geq 0.95$ & $\leq 0.05$ & $>0.95$ & $>0.75$ \\
\hline
\end{tabular}

Notes: PCFI $=$ Parsimony-adjusted Fit index, CFI $=$ Comparative Fit index; GFI $=$ Goodness of Fit index; NFI = Normed Fixed index; TLI = Tucker-Lewis index; RNI = Relative Noncentrality Fit index; RMSEA = Root Mean Square Error of Approximation.

\subsection{Moderating effects (Internet and smartphone)}

The results of Table 7 showed the significant effect of the Internet and smartphone between digital media marketing channels and brand awareness. As indicated in Table 7 the multiplicative effect of digital media marketing tools, and moderating variables demonstrated the significant effect because all the corresponding probabilities are less than 0.05 . Hence, it is concluded that the null hypotheses $\mathrm{H}_{1 \mathrm{~A}}, \mathrm{H}_{2 \mathrm{~A}}, \mathrm{H}_{1 \mathrm{~B}}, \mathrm{H}_{2 \mathrm{~B}}, \mathrm{H}_{1 \mathrm{C}}$, and $\mathrm{H}_{2 \mathrm{C}}$ have been rejected. It is further concluded that the Internet and smartphone have significant effects as moderating variables between digital media marketing channels and brand awareness.

Table 7. Moderating effect of internet and smartphone (technology)

\begin{tabular}{ccccccccc}
\hline Hypotheses & Moderators & Moderation & Coefficient & $\mathrm{SE}$ & $\mathrm{T}$ & $\mathrm{P}$ & LLCI & ULCI \\
\hline \multicolumn{7}{c}{ Moderating effect of the technology between email marketing and brand awareness } \\
\hline $\mathrm{H}_{1 \mathrm{~A}}:$ & Internet & $\mathrm{EM} \times \mathrm{INT}$ & -0.094 & 0.007 & -15.37 & 0.00 & -0.108 & -0.071 \\
\hline $\mathrm{H}_{2 \mathrm{~A}}:$ & Smartphone & $\mathrm{EM} \times \mathrm{SMP}$ & -0.197 & 0.007 & -27.34 & 0.00 & -0.211 & -0.183 \\
\hline \multicolumn{7}{c}{ Moderating effect of the technology between mobile marketing and brand awareness } \\
\hline $\mathrm{H}_{1 \mathrm{~B}}:$ & Internet & $\mathrm{MM} \times \mathrm{INT}$ & -0.035 & 0.005 & -7.19 & 0.00 & -0.045 & -0.026 \\
\hline $\mathrm{H}_{2 \mathrm{~B}}:$ & Smartphone & $\mathrm{MM} \times \mathrm{SMP}$ & -0.103 & 0.007 & -15.06 & 0.00 & -0.117 & -0.089 \\
\hline $\mathrm{Moderating}$ effect of the technology between social media marketing and brand awareness \\
\hline $\mathrm{H}_{1 \mathrm{C}}:$ & Internet & $\mathrm{SMM} \times \mathrm{INT}$ & -0.054 & 0.006 & -8.89 & 0.00 & -0.066 & -0.043 \\
\hline $\mathrm{H}_{2 \mathrm{C}}:$ & Smartphone & $\mathrm{SMM} \times \mathrm{SMP}$ & -0.144 & 0.008 & -19.14 & 0.00 & -0.159 & -0.129 \\
\hline
\end{tabular}

Note: ' $\times$ ' is known as the multiplicative sign; * denotes rejection of the hypotheses at 0.05 level $(\mathrm{p}<0.05)$. 


\subsection{Conditional effect of technology (moderator)}

Results of Table 8 validated the significant effect of Internet and smartphone. The results of Table 8 confirmed that at different values of quantitative moderators are mean of plus/minus one standard deviation ( \pm 1 SD) from the mean value (Bolin 2014). The conditional effect of the digital media marketing tools on the brand awareness at three values, the Internet, and smartphone are significant because the corresponding probabilities are less than 0.05 .

Table 8. Conditional effects

\begin{tabular}{ccccccc}
\hline & Effect & SE & T & P* & LLCI & ULCI \\
\hline \multicolumn{2}{c}{ Conditional effect of email marketing on brand awareness on different values of the Internet } \\
\hline 2.7102 & 0.2423 & 0.0107 & 22.59 & 0.0000 & 0.2213 & 0.2633 \\
\hline 3.8678 & 0.2314 & 0.0124 & 18.60 & 0.0000 & 0.2070 & 0.2557 \\
\hline 5.0000 & 0.2207 & 0.0171 & 12.92 & 0.0000 & 0.1872 & 0.2541 \\
\hline Conditional effect of email marketing on brand awareness on different values of the smartphone \\
\hline 2.7107 & 0.6317 & 0.0171 & 36.90 & 0.0000 & 0.5981 & 0.6653 \\
\hline 3.8690 & 0.4033 & 0.0156 & 25.82 & 0.0000 & 0.3727 & 0.4339 \\
\hline 5.0000 & 0.1802 & 0.0182 & 9.91 & 0.0000 & 0.1446 & 0.2159 \\
\hline
\end{tabular}

Conditional effect of mobile marketing on brand awareness on different values of the Internet

\begin{tabular}{lllllll}
\hline 2.7102 & 0.3514 & 0.0199 & 17.68 & 0.0000 & 0.3124 & 0.3904 \\
\hline 3.8678 & 0.3105 & 0.0208 & 14.96 & 0.0000 & 0.2698 & 0.3512 \\
\hline 5.0000 & 0.2706 & 0.0230 & 11.77 & 0.0000 & 0.2255 & 0.3156 \\
\hline
\end{tabular}

Conditional effect of mobile marketing on brand awareness on different values of the smartphone

\begin{tabular}{lllllll}
\hline 2.7107 & 0.8498 & 0.0129 & 65.64 & 0.0000 & 0.8244 & 0.8752 \\
\hline 3.8690 & 0.7303 & 0.0144 & 50.58 & 0.0000 & 0.7020 & 0.7586 \\
\hline 5.0000 & 0.6136 & 0.0192 & 31.90 & 0.0000 & 0.5759 & 0.6513 \\
\hline
\end{tabular}

Conditional effect of social media marketing on brand awareness on different values of the Internet

\begin{tabular}{ccccccc}
\hline 2.7102 & 0.1766 & 0.0136 & 13.03 & 0.0000 & 0.1500 & 0.2032 \\
\hline 3.8678 & 0.1141 & 0.0160 & 7.13 & 0.0000 & 0.0827 & 0.1455 \\
\hline 5.0000 & 0.0530 & 0.0205 & 2.58 & 0.0100 & 0.0127 & 0.0932 \\
\hline
\end{tabular}

Conditional effect of social media marketing on brand awareness on different values of the smartphone

\begin{tabular}{lllllll}
\hline 2.7107 & 0.5429 & 0.0158 & 34.33 & 0.0000 & 0.5119 & 0.5739 \\
\hline 3.8690 & 0.3762 & 0.0169 & 22.21 & 0.0000 & 0.3430 & 0.4094 \\
\hline 5.0000 & 0.2133 & 0.0217 & 9.85 & 0.0000 & 0.1709 & 0.2558 \\
\hline
\end{tabular}

Notes: * denotes rejection of the hypotheses at 0.05 level $(\mathrm{p}<0.05)$; Quantitative values for moderators are mean and \pm 1 SD from the mean; Level of confidence for all confidence intervals in output: 95.00. 


\subsection{Visualization of conditional effect}

It is imperative to understand that the confirmation of moderating impact through visualization is mandatory for the final conclusion of moderation (Bolin 2014). Thus, we have plotted 3D visualization for the conditional effect of the digital media marketing tools on the brand awareness at different values of quantitative moderators. The results of $3 \mathrm{D}$ plots of Figure 1 exhibited that there is a change on the effect of brand awareness at different values of Internet and smartphone in a relationship with digital media marketing channels.
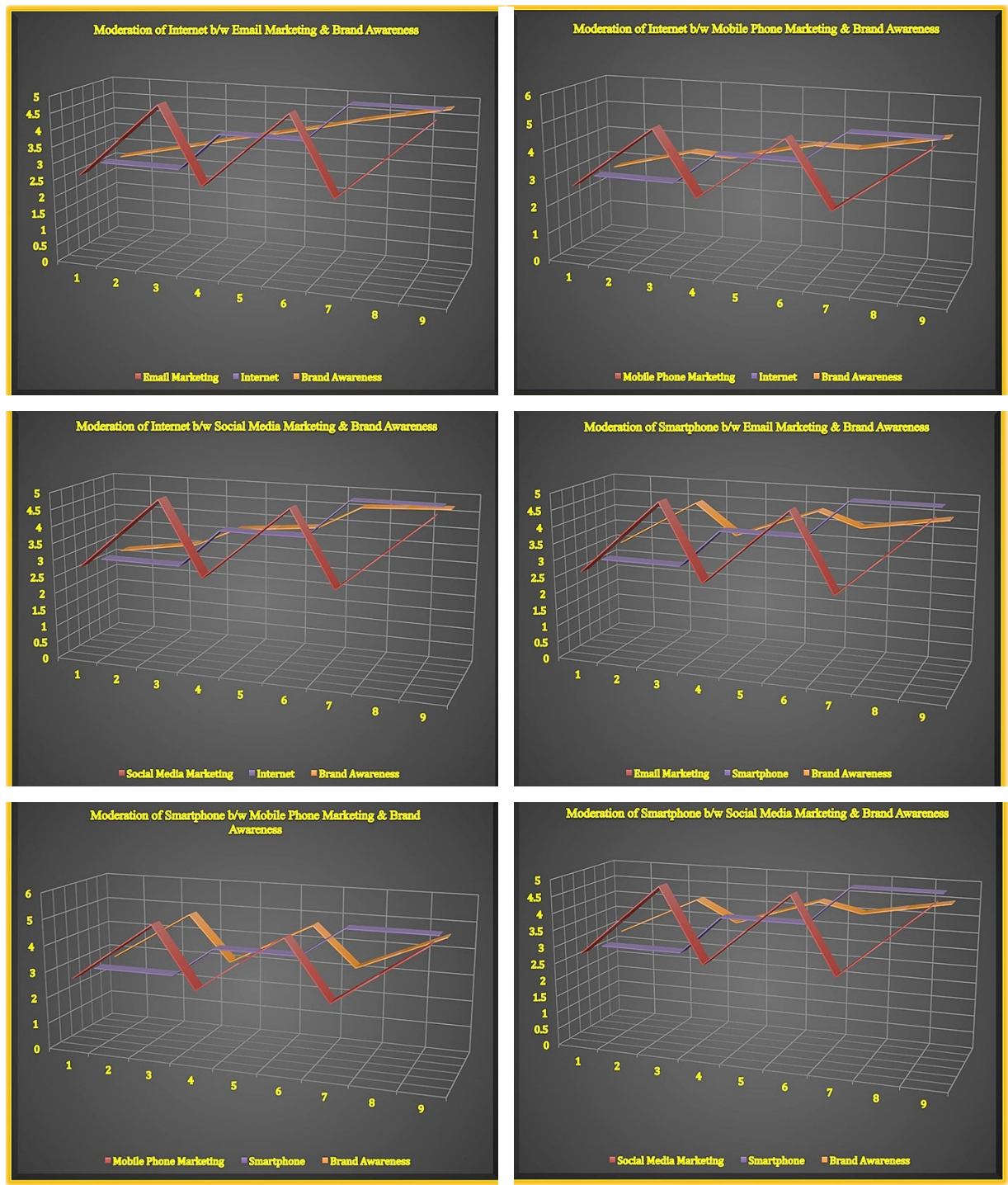

Fig. 1. 3D Plots of the interaction of digital media marketing tools with Internet and smartphone as moderating variables and their visualizing conditional impact on brand awareness 


\subsection{Direct effects of predictors}

Results of Table 9 exhibited the direct relationship of digital media marketing channels and the Brand awareness. The relationship between email marketing and brand awareness supported the $\mathrm{H}_{3}$ hypothesis. Since the probability is less than 0.05 , thus, the null hypothesis $\mathrm{H}_{3}$ has been rejected, and concluded that email marketing tool has a positive and significant effect on the brand awareness. Similarly, the hypotheses $\mathrm{H}_{4}$ and $\mathrm{H}_{5}$ are also rejected because the corresponding probabilities are less than 0.05 . Thus, it is established that the mobile phone marketing and social media marketing have a positive and significant impact on the brand awareness.

Table 9. Hypotheses testing summary for direct effect

\begin{tabular}{|c|c|c|c|c|c|c|c|c|c|}
\hline \multicolumn{3}{|c|}{ Direct Relationship } & \multirow{2}{*}{$\begin{array}{c}\text { Effect }(\beta) \\
0.212 \\
\end{array}$} & \multirow{2}{*}{$\begin{array}{c}\text { SE } \\
0.017 \\
\end{array}$} & \multirow{2}{*}{$\begin{array}{c}\mathrm{T} \\
12.34 \\
\end{array}$} & \multirow{2}{*}{$\begin{array}{c}\mathrm{P} \\
0.00 \\
\end{array}$} & \multirow{2}{*}{$\begin{array}{l}\text { LLCI } \\
0.178 \\
\end{array}$} & \multirow{2}{*}{$\begin{array}{l}\text { ULCI } \\
0.245 \\
\end{array}$} & \multirow{2}{*}{$\begin{array}{c}\text { Decision } \\
\text { Supported }\end{array}$} \\
\hline $\mathrm{H}_{3}: \mathrm{EM} \uparrow$ & $\rightarrow$ & BA & & & & & & & \\
\hline $\mathrm{H}_{4}: \mathrm{MM}+$ & $\rightarrow$ & BA & 0.682 & 0.013 & 51.48 & 0.00 & 0.656 & 0.708 & Supported \\
\hline $\mathrm{H}_{5}: \mathrm{SMM} \dagger$ & $\rightarrow$ & BA & 0.261 & 0.018 & 14.89 & 0.00 & 0.227 & 0.296 & Supported \\
\hline
\end{tabular}

Notes: $\dagger=$ Predictor; BA $=$ Brand Awareness; EM = Email Marketing; $\mathrm{MM}=$ Mobile Marketing; $\mathrm{SMM}=$ Social Media Marketing; $\mathrm{DV}=$ Dependent variable $=$ Brand Awareness; ${ }^{*} \mathrm{p}<0.05$.

\subsection{Mediating effects using bootstrapping method}

As we have to examine the impact of three mediating variables such as the perceived value, word of mouth, and trust. We have used the bootstrapping method to investigate the influence of mediating variables (Bolin 2014). We developed three sets of hypotheses $\mathrm{H}_{6 \mathrm{~A}}-\mathrm{H}_{6 \mathrm{C}}$ (for mediation of perceived value, trust, and word of mouth between email marketing and brand awareness), $\mathrm{H}_{7 \mathrm{~A}}-\mathrm{H}_{7 \mathrm{C}}$ (for mediation of perceived value, word of mouth, and trust between mobile marketing and brand awareness), and $\mathrm{H}_{8 \mathrm{~A}}-\mathrm{H}_{8 \mathrm{C}}$ (for mediation of perceived value, trust, and word of mouth between social media marketing and brand awareness). As the results of Table 10 exhibited that the null hypotheses $\mathrm{H}_{6 \mathrm{~B}}, \mathrm{H}_{6 \mathrm{C}}, \mathrm{H}_{8 \mathrm{~B}}$ and $\mathrm{H}_{8 \mathrm{C}}$ have been rejected because the zero does not lie between Boot LLCIs and Boot ULCIs, thus, it is concluded that email marketing and social media channels and brand awareness are mediated by the word of mouth and trust. Similarly, the null hypotheses $\mathrm{H}_{7 \mathrm{~A}}$ and $\mathrm{H}_{7 \mathrm{~B}}$ have also been rejected, and it is demonstrated that the mobile marketing tool and brand awareness are mediated by the perceived value, and trust. However, the null hypotheses $\mathrm{H}_{6 \mathrm{~A}}, \mathrm{H}_{7 \mathrm{C}}$ and $\mathrm{H}_{8 \mathrm{~A}}$ do not reject because zero does lie between Boot LLCIs and Boot ULCIs, therefore, it is concluded that the social media and email marketing tools and brand awareness is not mediated by the perceived value, and mobile marketing and brand awareness is not mediated by the word of mouth. 
Table 10. Mediating effects (bootstrapping method)

\begin{tabular}{|c|c|c|c|c|c|c|}
\hline Hypotheses & Mediators & $\begin{array}{c}\text { Indirect } \\
\text { Effect }\end{array}$ & Boot SE & $\begin{array}{l}\text { Boot } \\
\text { LLCI }\end{array}$ & $\begin{array}{l}\text { Boot } \\
\text { ULCI }\end{array}$ & Decision \\
\hline \multicolumn{7}{|c|}{ Indirect effect of email marketing on brand awareness } \\
\hline $\mathrm{H}_{6 \mathrm{~A}}:$ & Perceived Value & -0.0001 & 0.0015 & -0.0028 & 0.0029 & Insignificant \\
\hline $\mathrm{H}_{6 \mathrm{~B}}:$ & Trust & 0.2180 & 0.0168 & 0.1838 & 0.2499 & Significant \\
\hline \multirow[t]{2}{*}{$\mathrm{H}_{6 \mathrm{C}}:$} & Word of Mouth & 0.3909 & 0.0147 & 0.3611 & 0.4197 & Significant \\
\hline & Total Indirect Effect & 0.6088 & 0.0169 & 0.5761 & 0.6418 & Significant \\
\hline \multicolumn{7}{|c|}{ Indirect effect of mobile marketing on brand awareness } \\
\hline $\mathrm{H}_{7 \mathrm{~A}}:$ & Perceived Value & 0.0041 & 0.0016 & 0.0010 & 0.0074 & Significant \\
\hline $\mathrm{H}_{7 \mathrm{~B}}$ : & Trust & 0.1919 & 0.0121 & 0.1676 & 0.2153 & Significant \\
\hline \multirow[t]{2}{*}{$\mathrm{H}_{7 \mathrm{C}}:$} & Word of Mouth & 0.0228 & 0.0150 & -0.0061 & 0.0527 & Insignificant \\
\hline & Total Indirect Effect & 0.2188 & 0.0120 & 0.1958 & 0.2431 & Significant \\
\hline \multicolumn{7}{|c|}{ Indirect effect of social media marketing on brand awareness } \\
\hline $\mathrm{H}_{8 \mathrm{~A}}:$ & Perceived Value & -0.0013 & 0.0019 & -0.0051 & 0.0023 & Insignificant \\
\hline $\mathrm{H}_{8 \mathrm{~B}}:$ & Trust & 0.2206 & 0.0163 & 0.1885 & 0.2524 & Significant \\
\hline \multirow[t]{2}{*}{$\mathrm{H}_{8 \mathrm{C}}$ : } & Word of Mouth & 0.3749 & 0.0150 & 0.3448 & 0.4042 & Significant \\
\hline & Total Indirect Effect & 0.5943 & 0.0165 & 0.5630 & 0.6278 & Significant \\
\hline
\end{tabular}

\section{Conclusions}

The findings of the research revealed that the digital media marketing tools such as mobile marketing, social media marketing, and email marketing channels have a direct and positive significant impact on brand awareness. The mobile channel has the most powerful impact and followed by the social media-marketing tool in creating the brand awareness. Results of the indirect effects concluded that the trust and word of mouth are important factors in reshaping the minds of customers in order to create the brand awareness by using the email marketing and social media marketing channels, and perceived value and trust have a significant indirect effect on mobile marketing tool and brand awareness. The results of the study concluded that both Internet and smartphones have a significant moderating effect on the digital media marketing channels and brand awareness. The individual outcomes exhibited that the Internet has a more significant moderating effect on the email marketing and social media communication tools as compared to the smartphones. However, in the case of mobile marketing the smartphone has more significant impact than the Internet as moderator in creating the brand awareness.

The undertaken research provides a ground to the brand managers, and policymakers to decide how to devise the certain strategies for the effectiveness of marketing campaigns through interactive digital media channels. More concerned with the practical implications of this study, marketers and brand managers should be thoughtful about customers' 
psychological factors to comprehend the customer adoption for the interactive digital media channels in order to respond their brands. The results of this research also provide the insights and importance of technology factors of this new media, so, companies may prepare the required technology platforms for effective communication to the online customers. Since, now, the technology changes in hours not in months, therefore, the results of this study also provide the conclusive evidence of the importance of the technological factors. Overall, the undertaken research is mainly contributed to the literature concerning the theory development of interactive digital media communication, and the impact of attitude and technology on the brand awareness.

However, the study has certain limitation such as the data has been collected through online modes, thus, it might be the chances of respondents' error, thus, the self-administered questionnaire may eradicate this problem. Secondly, we have received the responses only from the major cities of the selected countries; hence, results of small cities and rural areas are lacking the representation. We have used only three interactive media channels, whereas, search engine optimization, companies websites, and search engine marketing channels may give more exclusive and robust results. Thus, the future studies may incorporate these channels to examine the comprehensive role of interactive digital media in creating the brand awareness. We applied SEM and this test does not provide any explanation for causality, whereas many researchers are implicitly interested to measure the causal modeling. Therefore, forthcoming studies can develop causal models under the influential approach on causal effect and causation to understand the behavioral intentions of a customer. Moreover, future studies may include more mediating and moderating variables for a better understanding of customers' attitude and impact of technological factors on brand awareness.

\section{References}

Aaker, D. A. 1996. Measuring brand equity across products and markets, California Management Review 38(3): 102-12. https://doi.org/10.2307/41165845

Ahuja, V. 2015. Development of an optimal solution for digital marketing variables in an online tool, International Journal of Internet Marketing and Advertising 9(1): 49.

https://doi.org/10.1504/ijima.2015.068345

Ailawadi, K. L.; Lehmann, D. R.; Neslin, S. A. 2003. Revenue premium as an outcome measure of brand equity, Journal of Marketing 67(4): 1-17. https://doi.org/10.1509/jmkg.67.4.1.18688

Al-Meshal, S.; Almotairi, M. 2013. Consumer acceptance of mobile marketing: an empirical study on the Saudi female, International Journal of Marketing Studies 5(5): 94-100.

https://doi.org/10.5539/ijms.v5n5p94

Baldauf, A.; Cravens, K. S.; Binder, G. 2003. Performance consequences of brand equity management: evidence from organizations in the value chain, Journal of Product \& Brand Management 12(4): 220-236. https://doi.org/10.1108/10610420310485032

Blair, M. K. 2017. Using digital and social media platforms for social marketing. Oxford Medicine Online: Oxford University Press. https://doi.org/10.1093/med/9780198717690.003.0012

Bolin, J. H. 2014. Hayes, Andrew, F. (2013). Introduction to mediation, moderation and conditional process analysis: a regression-based approach, Journal of Educational Measurement 51(3): 335-337. https://doi.org/10.1111/jedm.12050 
Chitra, K.; Sasikala, K. 2016. Social media marketing strategies for enhancing brand awareness: a study with reference to select start-ups, Asian Journal of Research in Social Sciences and Humanities 6(9): 1081. https://doi.org/10.5958/2249-7315.2016.00856.x

Choi, Y. K.; Lee, S. 2015. Understanding mobile phone usage through a value-based approach: marketing implications. Encyclopaedia of Mobile Phone Behavior.

https://doi.org/10.4018/978-1-4666-8239-9.ch018

Çizmeci, F.; Ercan, T. 2015. The effect of digital marketing communication tools in the creation of brand awareness by housing companies, Megaron 10(2): 149-161.

https://doi.org/10.5505/megaron.2015.73745

Clark, M.; Melancon, J. 2013. The influence of social media investment on relational outcomes: a relationship marketing perspective, International Journal of Marketing 5(4): 132-142.

https://doi.org/10.5539/ijms.v5n4p132

Confos, N.; Davis, T. 2016. Young consumer-brand relationship building potential using digital marketing, European Journal of Marketing 50(11): 1993-2017.

https://doi.org/10.1108/ejm-07-2015-0430

Dimitriu, R.; Guesalaga, R. 2017. Consumers' social media brand behaviors: uncovering underlying motivators and deriving meaningful consumer segments, Psychology \& Marketing 34(5): 580-592. https://doi.org/10.1002/mar.21007

Filipovic, J. 2015. Brand awareness and buying intention in the online environment, Marketing 46(4): 277-284. https://doi.org/10.5937/markt1504277f

Fornell, C.; Larcker, D. F 1981. Evaluating structural equation models with unobservable variables and measurement error, Journal of Marketing Research 18(1): 39-50.

https://doi.org/10.2307/3151312

Gopal, R. D.; Tripathi, A. K.; Walter, Z. D. 2006. Economics of first-contact email advertising, Decision Support Systems 42(3): 1366-1382. https://doi.org/10.1016/j.dss.2005.11.004

Groeger, L.; Buttle, F. 2016. Deciphering word-of-mouth marketing campaign reach: everyday conversation versus institution alized word of mouth, Journal of Advertising Research 56(4): 368-384. https://doi.org/10.2501/jar-2016-043

Hanna, R.; Rohm, A.; Crittenden, V. L. 2011. We're all connected: the power of the social media ecosystem, Business Horizons 54: 265-273. http://dx.doi.org/10.1016/j.bushor.2011.01.007

Harrison, P.; Jackson, M. 2013. Integrated marketing communications and power imbalance: the strategic nature of marketing to children and adolescents by food and beverage companies, Chapter in J. Williams, K. Pasch, C. Collins (Eds.). Advances in communication research to reduce childhood obesity. New York, NY: Springer. https://doi.org/10.1007/978-1-4614-5511-0_3 Internet live stats (n. d.) [online], [cited 6 June 2017]. Available from Internet: www.InternetLiveStats.com

Kaiser, H. F. 1974. An index of factorial simplicity, Psychometrika 39(1): 31-36. https://doi.org/10.1007/bf02291575

Kaplan, A. M.; Haenlein, M. 2010. Users of the world, unite! The challenges and opportunities of social media, Business Horizons 53(1): 59-68. https://doi.org/10.1016/j.bushor.2009.09.003

Kerlinger, F. N.; Lee, H. B. 2000. Foundations of behavioral research. $4^{\text {th }}$ ed. Holt, NY: Harcourt College Publishers.

Kotler, P.; Keller, K. L.; Ancarani, F.; Costabile, M. 2014. Marketing management. $14^{\text {th }}$ ed. Pearson.

Leech, N. L.; Barrett, K. C.; Morgan, G. A. 2011. SPSS for intermediate statistics: use and interpretation. $4^{\text {th }}$ ed. Lawrence Erlbaum Association Inc. http://dx.doi.org/10.4324/9780203821848 
Mourad, M.; Ennew, C.; Kortam, W. 2011. Brand equity in higher education, Marketing Intelligence \& Planning 29(4): 403-420. https://doi.org/10.1108/02634501111138563

Muk, A.; Chung, C. 2015. Applying the technology acceptance model in a two-country study of SMS advertising, Journal of Business Research 68(1): 1-6.

https://doi.org/10.1016/j.jbusres.2014.06.001

Munsell, C. R.; Harris, J. L.; Sarda, V.; Schwartz, M. B. 2015. Parents' beliefs about the healthfulness of sugary drink options: opportunities to address misperceptions, Public Health Nutrition 19(1): 46-54. https://doi.org/10.1017/s1368980015000397

Pizzutti, C.; Fernandes, D. 2010. Effect of recovery efforts on consumer trust and loyalty in e-tail: a contingency model, International Journal of Electronic Commerce 14(4): 127-160.

https://doi.org/10.2753/jec1086-4415140405

Ribbink, D.; Riel, A. C. R. V.; Liljander, V.; Streukens, S. 2004. Comfort your online customer: quality, trust and loyalty on the Internet, Managing Service Quality 14(6): 446-644.

https://doi.org/10.1108/09604520410569784

Romaniuk, J.; Wight, S.; Faulkner, M. 2017. Brand awareness: revisiting an old metric for a new world, Journal of Product \& Brand Management 26 (5): 469-476.

https://doi.org/10.1108/jpbm-06-2016-1242

Rossiter, J. R.; Percy, L. 2017. Methodological guidelines for advertising research, Journal of Advertising 46(1): 71-82. https://doi.org/10.1080/00913367.2016.1182088

Rutherford, G. S. W.; Hair, J. F.; Anderson, R. E.; Tatham, R. L. 1988. Multivariate data analysis, The Statistician 37(4/5): 484. http://dx.doi.org/10.2307/2348783

Saini, R. 2017. Role of social media channels in promoting digital marketing - an exploratory study, Asian Journal of Research in Marketing 6(4): 16.

https://doi.org/10.5958/2277-6621.2017.00006.8

Stephen, A. T. 2016. The role of digital and social media marketing in consumer behavior, Current Opinion in Psychology 10: 17-21. https://doi.org/10.1016/j.copsyc.2015.10.016

Talarico, D. 2016. From inbox to enroll: email marketing tips, Recruiting \& Retaining Adult Learners 18(11): 1-3. https://doi.org/10.1002/nsr.30171

Virvilaite, R.; Tumasonyte, D.; Sliburyte, L. 2015. The influence of word of mouth communication on brand equity: receiver perspectives, Procedia-Social and Behavioral Sciences 213: 641-646. https://doi.org/10.1016/j.sbspro.2015.11.465

Weber, L. 2009. Marketing to the social web. New Jersey: John Wiley \& Sons, Inc. Hoboken.

Yasin, M.; Shamim, A. 2013. Brand love: mediating role in purchase intentions and word-of mouth, IOSR Journal of Business and Management 7(2): 101-109.

https://doi.org/10.9790/487x-072101109

Yoon, S. J. 2002. The antecedents and consequences of trust in online purchase decisions, Journal of Interactive Marketing 16(2): 47-63. https://doi.org/10.1002/dir.10008

Zeithaml, V. A. 1988. Consumer perceptions of price, quality and value: a means-end model and synthesis of evidence, Journal of Marketing 52(3): 2-22. https://doi.org/10.2307/1251446

Zhang, X. A.; Kumar, V.; Cosguner, K. 2017. Dynamically managing a profitable email marketing program, Journal of Marketing Research (in Press). https://doi.org/10.1509/jmr.16.0210 
Rizwan Raheem AHMED is a Professor at the faculty of management Sciences, Indus University, Karachi (Pakistan); He obtained his PhD from Hamdard University, and MS/M.Phil. (Economics) from SZABIST University, Karachi. He is also an independent consultant for the Pharmaceutical Industry for last several years. During his thorough research career of more than 12 years, he mainly focused on marketing strategy, digital marketing, organizational performance, and behavior of stocks, money market portfolios and liquidity market problems by using Time Series analysis models, Multivariate Regression, CFA and EFA models. Besides, he also made a significant research in current issues related to Sales and marketing of local and global Pharmaceutical Industry; he used quantitative and qualitative models for this purpose.

Jolita VVEINHARDT is Professor, PhD, Chief Researcher, Lithuanian Sports University, Institute of Sport Science and Innovations, and holds PhD from Vytautas Magnus University in Lithuania. Dr Jolita Vveinhardt has published over 100 peer-reviewed papers on human resource management, corporate social responsibility, mobbing and other issues.

Dalia ŠTREIMIKIENE is a Principal Research Fellow at Lithuanian Sports University, Institute of Sport Science and Innovations, and holds PhD from Vilnius Gediminas Technical University, Lithuania. Prof. Dr Dalia Štreimikienè has published over 200 peer-reviewed papers on multi-criteria decision-making, efficiency analysis, and energy and agricultural economics in such outlets as Applied Energy, Energy Policy, Renewable and Sustainable Energy Reviews. 